\title{
GC-MS ANALYSIS OF THE ESSENTIAL OIL OF SATUREJA SUBSPICATA BARTL. EX VIS. OF MOLDOVAN ORIGIN
}

\author{
Ion Dragalin ${ }^{\mathrm{a}}$, Aculina Aricu ${ }^{\mathrm{a}}$, Nina Ciocarlan ${ }^{\mathrm{b}}$, Alexandru Ciocarlan $^{\mathrm{a}, \mathrm{c}}$, Victoria Codita ${ }^{\mathrm{a}, \mathrm{c}}$ \\ ${ }^{a}$ Institute of Chemistry, Academy of Science of Moldova, 3, Academiei str., Chisinau MD 2028, Republic of Moldova \\ ${ }^{b}$ Botanical Garden (Institute) of Academy of Sciences of Moldova,18, Padurii str., Chisinau MD 2002, Republic of Moldova \\ 'Tiraspol State University, 5, Gh. Iablocikin str., Chisinau MD 2069, Republic of Moldova \\ *e-mail: iondragalin@yahoo.com,phone: (+37322) 739769
}

\begin{abstract}
For the first time the results of GC-MS analysis of Satureja subspicata L. oil of Moldovan origin are reported. The chemical profile includes forty-four constituents and consists mostly (97.86\%) of phenolic monoterpenes, monoterpene hydrocarbons, bicyclic sesquiterpenes and their oxygenated derivatives. A substantial quantitative and qualitative chemical differentiation of S. subspicata oil of Moldovan origin and reported oil of Croatian origin were found. The essential oil of S. subspicata L. plants cultivated in Republic of Moldova belongs to the carvacrol chemotype.
\end{abstract}

Keywords: Satureja subspicata L., essential oil, chemical profile, GC-MS analysis.

Received: October 2016/ Revised final: November 2016/ Accepted: November 2016

\section{Introduction}

Numerous studies have been conducted on Satureja L. species, growing in different world regions, particularly on its volatile oil composition. According to these data, essential oils from Satureja species have a very complex composition, which includes phenolic monoterpenes, monoterpene hydrocarbons, bicyclic sesquiterpenes, other terpene derivatives and flavonoids [1-4].

A wide range of biological activities have been reported for different species of Satureja L.: anti-inflammatory [5], anti-HIV [6], antidiabetic, antioxidant, antimicrobial and antihyperlipidemic [7], antifungal [8], antispasmodic and antidiarrheal [9], vasodilatory [10] and cytotoxic [11].

The present studies are related to Satureja subspicata Bartl. ex Vis. cultivated in the Botanical Garden (Institute) of Academy of Science of Moldova (ASM), Collection of Medicinal Plants. Climate of the Republic of Moldova is favourable for $S$. subspicata, where plants have normal growth rhythms and successfully attain the generative period.

Up to date a few reports on essential oil composition and biological activity of $S$. subspicata species have been published. The volatile oil of $S$. subspicata possesses a big part of activities mentioned before, and is therefore a potential source of antimicrobial ingredients for the food and pharmaceutical industry.

The aim of this work is to reveal the chemical composition of $S$. subspicata essential oil cultivated in climatic and soil conditions specific for Republic of Moldova by means of GC-MS analysis.

\section{Experimental}

Materials

The plant material Satureja subspicata of Moldovan origin (aerial parts with inflorescence) for the chemical analyses was collected during flowering stage in July 2016 from experimental fields of the Botanical Garden (Institute) of ASM. The plants were cultivated in ecological conditions and without fertilizer use. Voucher specimen is deposited in the Herbarium of the Botanical Garden (Institute) of ASM.

Methods

Essential oil of $S$. subspicata was obtained by hydrodistillation $(600 \mathrm{~mL})$ of the aerial parts of the plant $(200 \mathrm{~g})$ for 2 hours in a Clevenger apparatus. After phase separation, volatile oil was dried over anhydrous sodium sulphate, and then used for chromatographic measurements.

The GC-MS analysis of the S. subspicata essential oil was carried out on an Agilent Technologies 7890A system with 5975C Mass-Selective Detector (GC-MSD) equipped with split-splitless injector (split, $250^{\circ} \mathrm{C}$, split ratio 1:50,1 $\mu \mathrm{L}$ ) and $\mathrm{HP}-5 \mathrm{~ms}$ capillary calibrated column $(30 \mathrm{~m}$ x $0.25 \mathrm{~mm}$ x $0.25 \mathrm{~mm})$; The carrier gas: helium $1.1 \mathrm{~mL} / \mathrm{min}$; oven: $70^{\circ} \mathrm{C}-2 \mathrm{~min}, 5^{\circ} \mathrm{C} / \mathrm{min}-200^{\circ} \mathrm{C}-20 \mathrm{~min}-300^{\circ} \mathrm{C}-5 \mathrm{~min}$; MSD in scan $30-300 \mathrm{amu}, 15 \mathrm{~min}$, 30-450 amu, solvent delay $3 \mathrm{~min}$.

\section{Results and discussion}

By hydrodistillation of plant material a whitish coloured volatile oil $\left(\mathrm{n}^{18}{ }_{\mathrm{D}}=1.5020\right)$ was obtained. The GC-MS analysis of $S$. subspicata oil resulted in identification of 44 components (see Figure 1 and Table 1). These components represent $97.86 \%$ of the oil and were identified by comparison of the acquired mass spectra with those from apparatus database. The mass spectrum of the major component carvacrol (RT-13.54) is depicted in Figure 2. 


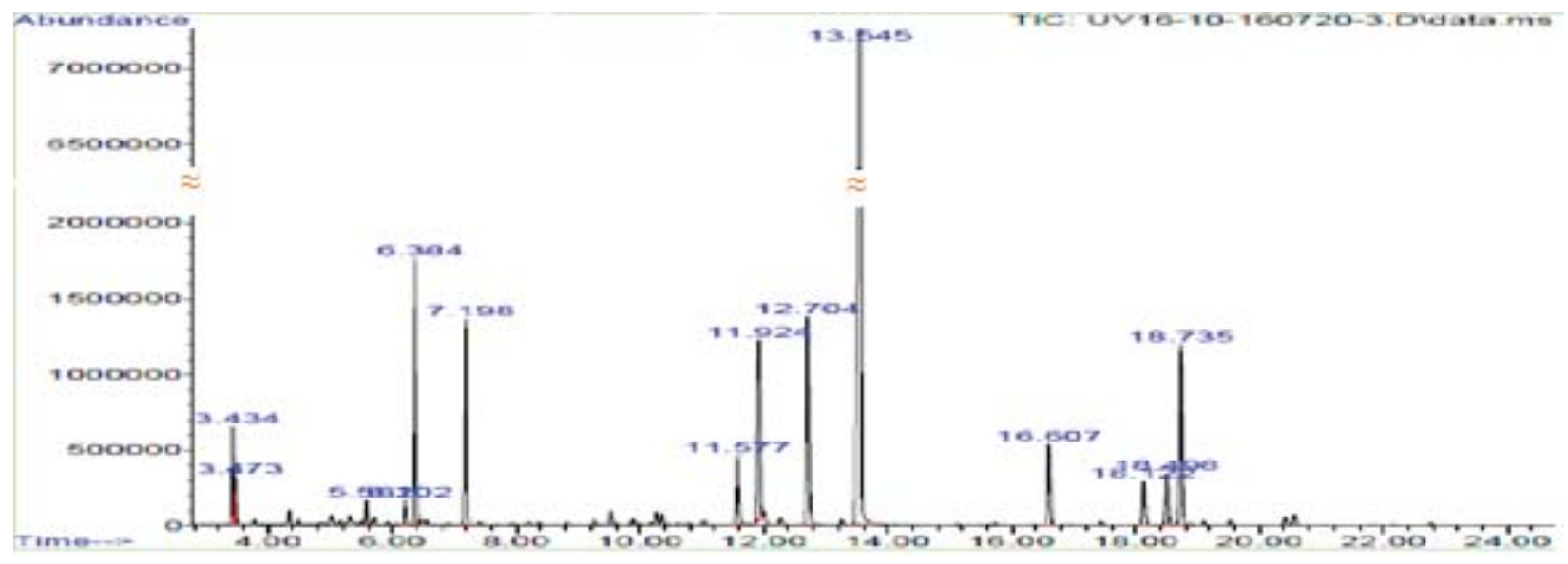

Figure 1. Cromatografic profile of $S$. subspicata essential oil.

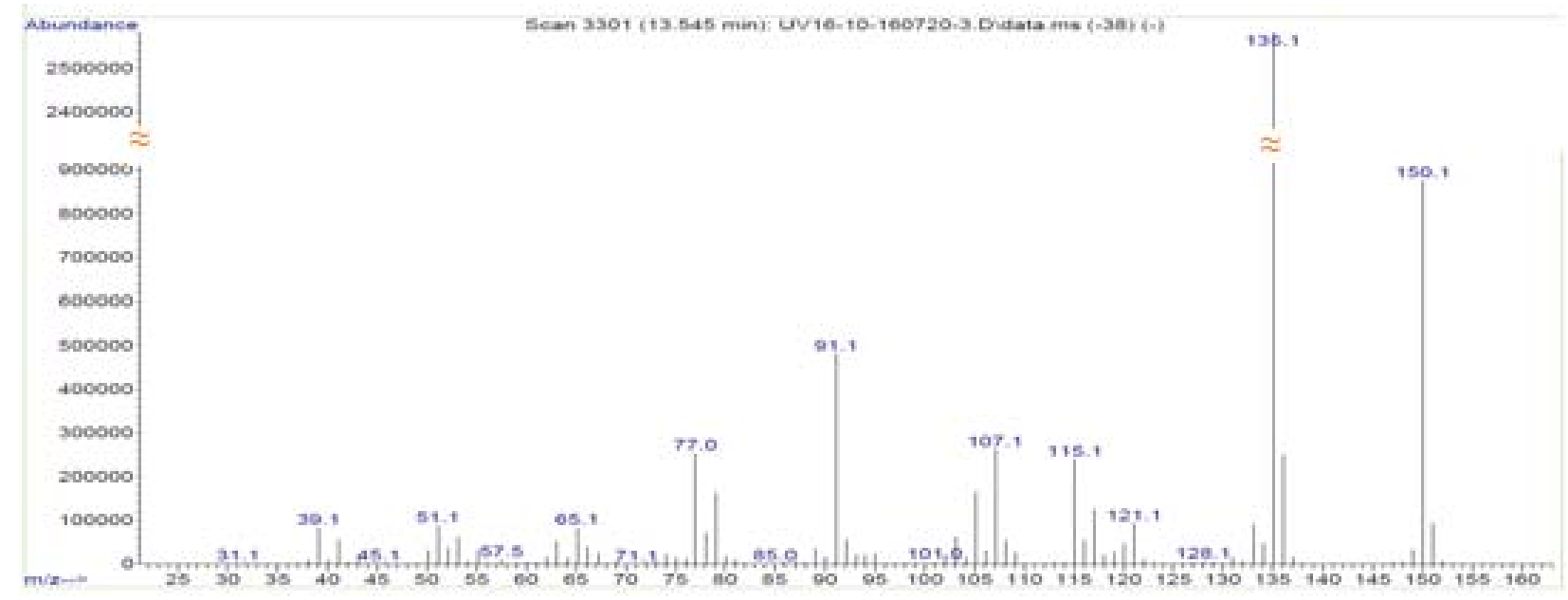

Figure 2. Mass spectrum of carvacrol (1).

According to GC-MS analysis, the most abundant component of S. subspicata essential oil is phenolic terpene carvacrol 1 (47.56\%), followed by monoterpene hydrocarbons $p$-cimen 2 (6.94) and $\gamma$-terpinene $3(5.54 \%)$, alchohol nerol $4(2.15 \%)$, aldehydes $(E)$-citral $5(7.23 \%)$ and $(Z)$-citral $6(5.73 \%)$ (Figure 3, Table 1); sesquiterpenes (+)- $\beta$-bisabolene 7 (5.80\%), $\beta$-caryophyllene 8 (2.61\%), germacrene B 9 (1.78\%) and germacrene D 10 (1.42\%) (Figure 4, Table 1). The reported compounds accounted for $97.86 \%$ of total content of the essential oil.<smiles>[R]c1cc(C(C)C)ccc1C</smiles>

$1 \mathrm{R}=\mathrm{OH}$

$2 \mathrm{R}=\mathrm{H}$<smiles>CC1=CCC(C(C)C)=CC1</smiles>

3<smiles>CC/C=C(/C)CCC=C(C)C</smiles>

4<smiles>CC(C)=CCC/C(C)=C\C=C(C)/C=C(\C)CCC=C(C)C</smiles>

5
6

Figure 3. Monoterpenes. 


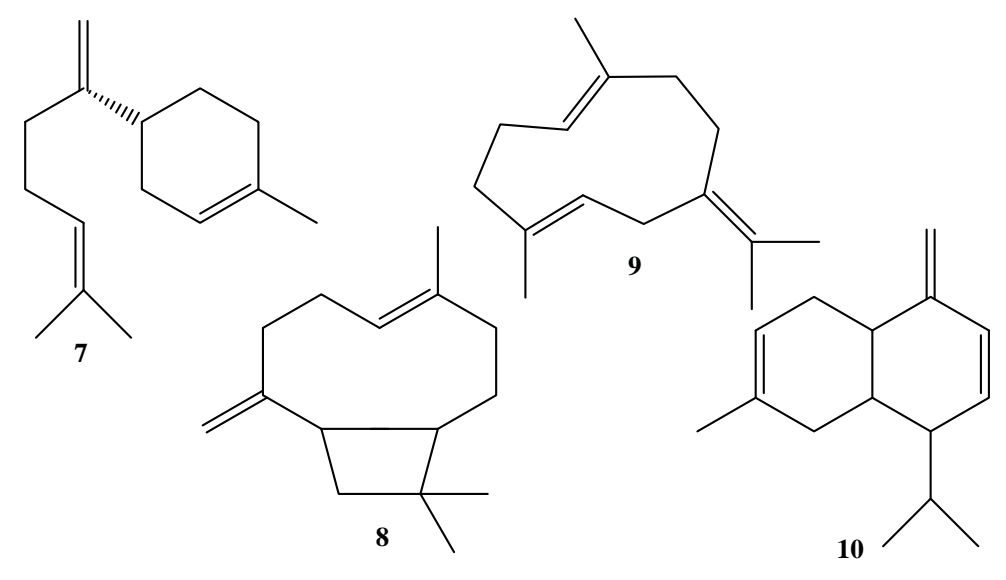

Figure 4. Sesquiterpenoids.

It must be mentioned, that the $S$. subspicata essential oil of Moldovan origin showed significant difference in qualitative and quantitative chemical composition in comparison with the reported from native area. S. subspicata essential oil of Croatian origin contains carvacrol (16.76\%) as major constituent, followed by $\alpha$-pinene (13.58\%), p-cymene (10.75\%) and $\gamma$-terpinene (9.54\%) [12]. According to Dunkić V. et al., the major component of the essential oil of two S. subspicata subspecies (S. subspicata ssp. subspicata and S. subspicatas sp. liburnica) is monoterpenic hydrocarbon $\alpha$-pinene (yield $52.9 \%$ and $42.6 \%$, respectively) and it means that both taxa belong to $\alpha$-pinene chemotype [13]. The carvacrol content $(16.8 \%$ and $13.5 \%$, respectively) reported by these authors is three times smaller than its content in S. subspicata oil of Moldovan origin.

Another team of researchers reported $\alpha$-pinene $(24.2 \%)$ as main compound of the essential oil from wild-grown $S$. subspicata in the Mediterranean part of Croatia, while carvacrol constitutes only 2.7\% [14]. The S. subspicata species originating from Bosnia and Herzegovina contain thymol (28.6\%) and carvacrol (27.9\%) as main compounds of their essential oils [15].

Phytochemical composition of $S$. subspicata essential oil of Moldovan origin.

\begin{tabular}{|c|c|c|c|c|c|c|c|}
\hline No & $\begin{array}{l}R T^{*} \\
\text { (min) }\end{array}$ & Component & $\%$ & No & $\begin{array}{l}R T^{*} \\
(\mathrm{~min})\end{array}$ & Component & $\%$ \\
\hline 1 & 3.434 & Isoamyl acetate & 1.98 & 23 & 9.885 & Borneol & 0.17 \\
\hline 2 & 4.344 & Origanene & 0.36 & 24 & 10.271 & 1-Terpinen-4-ol & 0.39 \\
\hline 3 & 4.496 & $\alpha$-Pinene & 0.14 & 25 & 10.360 & (Z)-Verbenol & 0.34 \\
\hline 4 & 4.863 & Isocumene & 0.06 & 26 & 10.624 & $\alpha$-Terpineol & 0.08 \\
\hline 5 & 5.018 & 1-Ethyl-3-methylbenzen & 0.31 & 27 & 10.787 & Pulegone & 0.10 \\
\hline 6 & 5.270 & Sabinene & 0.04 & 28 & 11.038 & Myrtenol & 0.22 \\
\hline 7 & 5.316 & 1-Octen-3-ol & 0.25 & 29 & 11.577 & Nerol & 2.15 \\
\hline 8 & 5.502 & Heptenone & 0.10 & 30 & 11.924 & (Z)-Citral & 5.73 \\
\hline 9 & 5.581 & $\beta$-Myrcene & 0.59 & 31 & 11.999 & Isothymol methyl ether & 0.46 \\
\hline 10 & 5.696 & 1,2,3-Trimethylbenzene & 0.23 & 32 & 12.271 & Geraniol & 0.28 \\
\hline 11 & 5.928 & $\alpha$-Phellandrene & 0.09 & 33 & 12.704 & (E)-Citral & 7.23 \\
\hline 12 & 6.202 & $\alpha$-Terpinene & 0.63 & 34 & 13.252 & Tymol & 0.17 \\
\hline 13 & 6.383 & $p$-Cymene & 6.94 & 35 & 13.545 & Carvacrol & 47.56 \\
\hline 14 & 6.489 & Limonene & 0.73 & 36 & 15.729 & $\alpha$-Bourbonene & 0.07 \\
\hline 15 & 6.564 & Eucalyptol & 0.14 & 37 & 16.607 & $\beta$-Caryophyllene & 2.61 \\
\hline 16 & 7.198 & $\gamma$-Terpinene & 5.54 & 38 & 17.447 & $\alpha$-Bisabolene & 0.13 \\
\hline 17 & 7.428 & Terpinene-4-acetate & 0.09 & 39 & 18.122 & Germacrene D & 1.42 \\
\hline 18 & 8.202 & Linalool & 0.16 & 40 & 18.498 & Germacrene B & 1.78 \\
\hline 19 & 8.370 & $\beta$-Pinene oxide & 0.10 & 41 & 18.735 & $(+)-\beta$-Bisabolene & 5.80 \\
\hline 20 & 8.832 & (E)-Sabinene-hydrate & 0.11 & 42 & 19.535 & $\alpha$-Caryophyllene & 0.21 \\
\hline 21 & 9.261 & Myrtanal & 0.19 & 43 & 20.416 & (-)-Spatulenol & 0.36 \\
\hline 22 & 9.533 & 2,2-Dimethylocta-3,4-dienal & 0.42 & 44 & 20.555 & Caryophyllene oxid & 0.40 \\
\hline
\end{tabular}


The list of secondary components of essential oils of Moldovan and Croatian origin, correspondingly, is comparable but differs quantitatively and includes: $\alpha$-pinene, limonene, $\alpha$-terpinene, thymol, linalool, $\beta$-myrcene, limonene, geraniol and others. In contrast with essential oil of Croatian origin, the studied by us oil is characterized by high content of unreported before components like $\gamma$-terpinene, $(E)$ - and $(Z)$-citral, $\beta$-bisabolene, nerol, $\beta$-caryophillene, germacrenes (B and D) and others. As a result, biological activity, pharmaceutical and perfumery value of $S$. subspicata oil of Moldovan origin can be much higher.

\section{Conclusions}

The quantitative and qualitative chemical differentiation of essential oil obtained from $S$. subspicata plants growing in Moldova and Croatia can be correlated with different geographic location and ecological conditions. The high content of the phenolic terpene carvacrol as a main component $(47.56 \%)$ suggests that $S$. subspicata plants cultivated in Republic of Moldova belong to a new high yielding carvacrol genotype.

\section{References}

1. Baser, K.H.C.; Tumen, G.; Satif, F.; Kirimer, N. Comparative morphological and chemical studies on Satureja species from west Anatolia. Book of abstracts, $2^{\text {nd }}$ Balkan Botanical Congress, Istanbul, 2000, pp. 129-132.

2. Slavkovska, V.; Jancic, R.; Bojovic, S.; Miloslavjevic, S.; Djoković, D. Variability of essential oils from Satureja montana L. and Satureja kitaibelii Wierzb. Ex Heuff. from the central part of the Balkan Peninsula. Phytochemistry, 2001, 57, pp. 71-76.

3. Tumen, G.; Kirimer, N.; Baser, K.H.C. The essential oils of Satureja occuring in Turkey: Basic and Applied Research. Book of abstracts, $27^{\text {th }}$ International Symposium on Essential Oils, Austria, 1997, pp. 250-254.

4. Tepe, B.; Cilkiz, M.A. Pharmacological and phytochemical overview on Satureja. Pharmaceutical Biology, 2016, 54(3), pp. 375-412.

5. Amanlou, M.; Dadkhah, F.; Salehnia, A.; Farsam, H.; Dehpour A. An anti-inflammatory and anti-nociceptive effects of hydrochloric extract of Satureja khuzistanica Jamzad extract. Journal of Pharmacy and Pharmaceutical Sciences, 2005, 8, pp. 102-106.

6. Yamasaki, K.; Nakano, M.; Kawahata, T.; Mori, H.; Otake, T.; Ueba, N.; Oishi, I.; Inami, R.; Yamane, M.; Nakamura, M.; Murata, H.; Nakanishi, T. Anti-HIV-l activity of herbs in Labiatae. Biological and Pharmaceutical Bulletin, 1998, 21, pp. 829-833.

7. Momtaz, S.; Abdollahi, M. An update on Pharmacology of Satureja species; From Antioxidant, Antimicrobial, Antidiabetes and Antihyperlipidemic to Reproductive Stimulation. International Journal of Pharmacology, 2010, 6(4), pp. 346-353.

8. Sokovic, M.; Sokovic, M.; Tzakou, O.; Pitarokili, D.; Couladis M. Antifungal activities of selected aromatic plants growing wild in Greece. Nahrung, 2002, 46, pp. 317-320.

9. Hajhashemi, V.; Sadraei, H.; Ghannadi, A.R.; Mohseni, M. Antispasmodic and antidiarrheal of Satureja hortensis L. essential oil. Journal of Ethnopharmacology, 2000, 71, pp. 187-192.

10. Sanchez de Pojas, V.R.; Somoza, B.; Ortega, T.; Villar, A.M.; Tejerina, T. Vasodilatory effect in rat aorta of eriodictyol obtained from Satureja obovata. Planta Medica, 1999, 65, pp. 234-238.

11. Stanojkovic, T.; Kolundzija, B.; Ciric, A.; Sokovic, M.; Nikolic, D.; Kundakovic, T. Cytotoxicity and antimicrobial activity of Satureja kitaibelii Wierzb. exHeuff (Lamiaceae). Digest Journal of Nanomaterials and Biostructures, 2013, 8, pp. 845-854.

12. Skočibusic, M.; Bezić, N.; Dunkić, V. Phytochemical composition and antimicrobial activities of the essential oils from Satureja subspicata Vis. growing in Croatia. Food Chemistry, 2006, 96(1), pp. 20-28.

13. Dunkić, V.; Bezić, N.; Ljubesić, N.; Bočina, I. Glandular hair ultrastructure and essential oils in Satureja subspicata Vis. ssp. subspicata and ssp. liburnica Šilić. Acta Biologica Cracoviensia, Series Botanica, 2007, 49(2), pp. 45-51.

14. Bezic, N.; Samanic, I.; Dunlic, V.; Besendorfer, V.; Puizina, J. Essential oil composition and internal transcribed spacet (ITS) sequience variability of four South-Croatian Satureja species (Lamiaceae). Molecules, 2009, 14, pp. 925-938.

15. Cavar, S.; Maksimović, M.; Šolić, M.E.; Jerković-Mujkić, A.; Bešta, R. Chemical composition and antioxidant and antimicrobial activity of two Satureja essential oils. Food Chemistry, 2008, 111, pp. 648-653. 